\title{
Nutrient Mineralization and Soil Biology as Influenced by Temperature and Fertilizer Management Practices
}

(Pemineralan Nutrien dan Biologi Tanih yang Dipengaruhi oleh Suhu dan Amalan Pengurusan Baja)

\author{
UMME AMINUN NAHER*, IMRAN ULlaH SARKER, AFSANA JAHAN, MD. MANIRUZZAMAN,
} APURBA KANTI CHOUDHURY, NAVIN KALRA \& JATISH CHANDRA BISWAS

\begin{abstract}
High soil temperature due to climate change may influence nutrient mineralization and soil biology. An incubation study was conducted at Bangladesh Rice Research Institute to determine the effect of temperature $\left(28^{\circ} \mathrm{C}\right.$ and $\left.45^{\circ} \mathrm{C}\right)$ on nutrient mineralization and soil microbial population of two different soils (terrace and saline soil) having different nutrient management practices (chemical fertilizer and integrated nutrient management). Terrace soil was clay loam and saline $\left(6 \mathrm{ds} \mathrm{m}^{-1}\right)$ soil was sandy loam in texture. Total $N$ and organic $C$ content was significantly high in terrace soil compared to saline soil. High temperature $\left(45^{\circ} \mathrm{C}\right)$ enhanced $\mathrm{C}$ mineralization by $33 \%$ in integrated nutrient management (INM) of terrace soil and $41 \%$ in chemical fertilizer treatment in saline soil. The $\mathrm{NH}_{4}^{+}-\mathrm{N}$ mineralization was increased by 3 fold in saline soil at $45^{\circ} \mathrm{C}$ as compared to the same at normal temperature of $28^{\circ} \mathrm{C}$. Temperature and nutrient management options also significantly influenced phosphorus $(P)$ and potassium $(K)$ mineralization. High temperature significantly enhanced $P$ mineralization in INM compared to chemical fertilizer amendment. In terrace soil, at $28^{\circ} \mathrm{C}$ temperature $\mathrm{K}$ mineralization was high in chemical fertilizer amended soil as compared to INM treatment. Temperature and nutrient sources affected soil bacterial population significantly compared to fungi, and actinomycetes. Phosphate solubilizing bacteria (PSB) were more resistant to high temperature compared to free-living $\mathrm{N}_{2}$ fixing bacteria. In general, high temperature and nutrient management practices affected $C, N, P, K$ mineralization and soil biology; although mode of action varied and depending on soil types and nutrient management practices.
\end{abstract}

Keywords: Climate change; integrated nutrient management; soil microorganisms; soil nutrient mineralization

\section{ABSTRAK}

Suhu tanih yang tinggi disebabkan oleh perubahan iklim boleh mempengaruhi biologi pemineralan dan nutrien tanih. Kajian inkubator yang telah dijalankan di Institut Penyelidikan Beras Bangladesh untuk menentukan kesan suhu $\left(28^{\circ} \mathrm{C}\right.$ dan $45^{\circ} \mathrm{C}$ ) terhadap nutrien pemineralan dan populasi mikrob tanih bagi dua tanih berbeza (tanih teres dan salin) yang mempunyai nutrien yang berbeza amalan pengurusan (baja kimia dan pengurusan nutrien bersepadu). Tanih teres lom liat dan tanih (6 ds $\mathrm{m}$-1) salin adalah lom tekstur berpasir. Jumlah $N$ dan kandungan $C$ organik adalah tinggi dalam tanih teres berbanding tanih salin. Suhu yang tinggi $\left(45^{\circ} \mathrm{C}\right)$ mempertingkatkan pemineralan $C$ sebanyak $33 \%$ dalam pengurusan nutrien bersepadu (INM) bagi tanih teres dan $41 \%$ dalam baja kimia rawatan bagi tanih salin. Pemineralan bagi $\mathrm{NH}_{4}^{+}-\mathrm{N}$ meningkat 3 kali lipatan dalam tanih salin pada suhu $45^{\circ} \mathrm{C}$ berbanding pada suhu biasa iaitu $28^{\circ} \mathrm{C}$. Suhu dan pengurusan nutrien juga mempengaruhi pemineralan fosforus $(P)$ dan kalium $(K)$. Suhu tinggi meningkatkan pemineralan $P$ dalam INM berbanding baja kimia pindaan. Dalam tanih teres, pada suhu $28^{\circ} \mathrm{C}$, pemineralan $K$ adalah tinggi dalam tanih baja kimia yang dipinda berbanding rawatan INM. Suhu dan sumber nutrien mempengaruhi populasi bakteria tanih secara signifikan berbanding kulat dan aktinomiset. Bakteria pemelarutan fosfat (PSB) berdaya tahan terhadap suhu tinggi berbanding bakteria hidup bebas N2. Secara amnya, suhu yang tinggi dan amalan pengurusan nutrien mempengaruhi pemineralan $C, N, P, K$ dan biologi tanih; namun mod tindakan yang berubah dan bergantung kepada jenis tanih dan amalan pengurusan nutrien.

Kata kunci: Mikroorganisma tanih; nutrien pemineralan tanih; pengurusan nutrien bersepadu; perubahan iklimf

\section{INTRODUCTION}

Global temperature is increasing because of climate change. Surface global temperature increased $0.6^{\circ} \mathrm{C}$ to $0.9^{\circ} \mathrm{C}$ between 1906 and 2005 (http://earthobservatory. nasa.gov) and global mean temperature is predicted to be increased by $2-7^{\circ} \mathrm{C}$ at the end of this century (Allison et al. 2009), which may have adverse impact on soil biology, organic matter mineralization and soil salinity. In Bangladesh due to climate change effect, area under salinity have been increased from 0.83 to 1.06 mha within last 27 years (Mahmud et al. 2016). In this situation, nutrient management practices in such soils becomes necessary to have better rice production. In addition, agricultural production could be severely affected in 
near future because of increasing summer and winter temperatures (Islam \& Neelim 2010).

Soil temperature directly influences microbial activity, as bacterial growth is rapid at higher temperature (van Gestel et al. 2016). Soil temperature also determined the temperature sensitivity of the microbial community by selecting a community adapted to the existing temperature regime. This has repeatedly been shown for bacterial growth in soil, both in natural temperature gradients (Rinnan et al. 2009; Tibbles \& Harris 1996), laboratory experiments (Bárcenas-Moreno et al. 2009; Birgander et al. 2013; Ranneklev \& Bååth 2001), and field experiments (Rousk et al. 2012). Similar results have also been found due to temperature shifts in composts (McKinley \& Vestal 1984); but adverse effect of rising temperature may act differently in various soil types having various pattern of nutrient mineralization. This situation demands special attention for nutrient management techniques required for crop production. The importance of temperature dependence soil organisms has been further emphasized during recent years due to the global warming issues, as soil microorganisms are the main player for producing $\mathrm{CO}_{2}$ and $\mathrm{CH}_{4}$ during decomposition of soil organic materials. In Bangladesh, farmers mainly rely on inorganic fertilizers for rice production, although some of them follow INM practices. The microbial community and nutrient release patterns are expected to vary under both fertilizer management options and increased temperature conditions for saline non-saline soils. Hence, the objectives of the present study were to determine the influence of temperature on nutrient mineralization from INM and chemical fertilizer amended saline and non-saline soils and to assess changes of microbial population and beneficial microbial community under varied temperature regimes and fertilizer management practices in those soils.

\section{MATERIALS AND METHODS}

\section{SOIL SAMPLE COLLECTION}

Saline soil was collected from paddy field located at coastal area of south east $\left(21.88^{\circ} \mathrm{N}, 90.24^{\circ} \mathrm{E}\right)$ part of Bangladesh. Farmers were cultivating rice in that soil since 15 years as a single crop by using mostly inorganic fertilizers. Grey terrace soil was collected from Bangladesh Rice Research Institute, Gazipur $\left(29.54^{\circ} \mathrm{N}, 90.24^{\circ} \mathrm{E}\right)$ research farm. This soil belongs to a long-term nutrient management experiment, which was initiated in 1985 and followed both inorganic and INM practices.

\section{TREATMENT APPLICATION AND SOIL INCUBATION}

Collected soil samples were air dried ground and sieved ( $2 \mathrm{~mm}$ mesh). Exactly $3 \mathrm{~kg}$ each type of sieved soil was filled in to the separate plastic pot and after imposing treatment pots were kept in incubator. Treatments imposed for both the soils were; $\mathrm{T}_{1}$-chemical fertilizer, N-P-K-S @ 135-18-82-20 kg ha-1 and $\mathrm{T}_{2}-$ INM (cow dung @ 3 ton ha-1 + N-P-K-S-@ 120-13.5-75.1-20 kg ha-1). After mixing inorganic fertilizer and organic matter, soil was moistened and incubated in an incubator at $28 \pm 2^{\circ} \mathrm{C}$, and $45 \pm 2^{\circ} \mathrm{C}$. Soil moisture was maintained as saturated for 1 month. Initial soil microbial and chemical properties such as; organic carbon (OC), N, P, K, were determined. Soil nutrient mineralization and changes in soil microbial population was measured after 3,6, 9, 14, 20 and 30 days of incubation. Design of the experiment was complete randomized design, with 2 factors (factor a: soil type and factor $b$ : fertilizer management practices). Treatment was replicated three times. Each plastic container was considered as replication of treatment.

\section{DETERMINATION OF NUTRIENT MINERALIZATION}

The organic $\mathrm{C}$ and total $\mathrm{N}$ were determined by wet oxidation method (Walkley \& Black 1935) and Kjeldhal method (Bremner \& Mulvaney 1982), respectively. Carbon mineralization rate $(k)$ was calculated as (Bustamante et al. 2008),

$$
k=2.303 \frac{\left(\log C_{o}-\log C\right)}{t}
$$

where $C_{o}$ is the initial carbon content and $C$ at the time (t). Available $\mathrm{P}$ in extract was determined by developing blue color with ascorbic acid-ammonium molybdate Vanadate complex and color intensity was measured colorometrically at 710 wavelengths in Jasco V630, Japan spectrophotometer (Murphy \& Riley 1962). Exchangeable $\mathrm{K}$ was extracted with $1 \mathrm{M} \mathrm{NH}_{4} \mathrm{OAc}$ at $\mathrm{pH} 7$ (Benton 2001) and measured using flame photometer, Sherwood model-410, UK.

\section{DETERMINATION OF SOIL MICROBIAL POPULATION}

Soil samples were collected in plastic bag and kept in ice box and preserved in the laboratory at $4^{\circ} \mathrm{C}$ until analyses. Microbial population was determined following total plate count method. Total bacterial population was counted using nutrient agar plate. Potato dextrose agar and actinomycetes isolated media were used to determine fungus and actinomycetes population, respectively. Freeliving $\mathrm{N}_{2}$ fixing bacteria population was determined in nitrogen-free media (Prasad et al. 2001) and phosphate solubilizing bacteria (PSB) population in national botanical research institute phosphate (NBRIP) media plates. For each type of microbial population determination, 10 grams of soil was taken during sampling and a serial dilution was made up to $10^{10}$ and $0.1 \mathrm{~mL}$ of each dilution was spread in respective media plates. Inoculated plates were incubated at $28^{\circ} \mathrm{C}$ temperature for 5 days. Population counted was started after 1 day of incubation and finished at day six.

\section{STATISTICAL ANALYSES}

Data were statistically analyzed for ANOVA using SPSS version 17.0. Treatment means were separated by 
Duncan's multiple range test (DMRT) test for any significant difference among the treatment means at $p<0.05$.

\section{RESULTS AND DISCUSSION}

\section{INITIAL SOIL BIO-CHEMICAL PROPERTIES}

Terrace soil was clay loam in texture, $\mathrm{pH} 6.8$ and contained $1.51 \%$ OC and $0.13 \%$ total nitrogen (TN) having adequate available $\mathrm{P}$ and $\mathrm{K}$ for rice production (Table 1). Total bacteria, free-living $\mathrm{N}_{2}$ fixing bacteria and PSB population were higher in terrace soil compared to saline soil. Saline soil (EC 6ds $\left.\mathrm{m}^{-1}\right)$ was slightly alkaline in nature $(\mathrm{pH} 7.8)$ and sandy loam in texture. Organic C $(0.67 \%)$, TN $(0.05 \%)$, available $\mathrm{P}(3.2 \mathrm{ppm})$ were low in this soil, but exchangeable $\mathrm{K}$ was higher than terrace soil.

\section{SOIL ORGANIC CARBON (OC) MINERALIZATION}

Initial SOC was high in terrace soil $(1.51 \%)$ compared to saline soil $(0.67 \%)$. After addition of cow dung ( 3 ton ha ${ }^{-1}$ dry weight) it was $1.6 \%$ in terrace and $0.74 \%$ in saline soil. Between the two nutrient management practices, OC content was high in INM treatment. In terrace soil, SOC gradually decreased over time irrespective of temperature and nutrient management practices. Several factors influenced soil $\mathrm{C}$ mineralization such as soil organic matter content, soil temperature (Bekku et al. 2004), soil texture (Siqueira Neto et al. 2010), soil structure (Co^te'et al. 2000), soil moisture (Craine \& Gelderman 2010) and activity of soil microorganism (Lange \& Green 2005) are important. In our study, we have found significantly higher $\mathrm{C}$ mineralization rate $(r)$ in saline soil compared to terrace soil (Figure 1). High temperature $\left(45^{\circ} \mathrm{C}\right)$ enhanced $\mathrm{C}$ mineralization in both the soils. Carbon mineralization enhanced by temperature was also reported by Deressa (2015) and Xe et al. (2007). In the terrace soil at $28^{\circ} \mathrm{C}, \mathrm{C}$ mineralization rate was slightly higher $(0.011)$ in chemical fertilizer amendment compared to INM treatment $(0.010)$, which might be due to available $\mathrm{NH}_{4}{ }^{+} \mathrm{N}$ from chemical fertilizer that favored microbial activity and stimulated $\mathrm{C}$ mineralization. High temperature influenced microbial mineralization of SOC (Xu et al. 2012). Evidences of soil organic matter decomposition increased with increasing temperature, is in agreement with our present study (Figure 1(a) \& 1(b)). In the study, at $45^{\circ} \mathrm{C}$ temperature, C mineralization rate was high in INM $(0.015)$ compared to chemical fertilizer (0.013) treatment (Table 2). In the INM treatment, $\mathrm{C}$ mineralization increased by $33 \%$ due to high temperature, which could be resultant effect of accelerated microbial activities.

In saline sandy loam soil, we have found faster SOC mineralization compared to clay loam terrace soil. Although loss of SOC varied with soil texture (Setia et al. 2011), clayey soils have more potential for SOC storage than sandy soils (Neto et al. 2010). In saline soil, SOC content sharply declined after 3 to 6 days of incubation and C mineralization was higher in chemical fertilizer amended soil compared to INM treatment. Availability of $\mathrm{NH}_{4}{ }^{+} \mathrm{N}$ from chemical fertilizer may induce $\mathrm{C}$ mineralization rate. At $28^{\circ} \mathrm{C}$ temperature, $\mathrm{C}$ mineralization rate was 0.020 in chemical fertilizer amended soil and 0.017 in INM treatment, respectively. At $45^{\circ} \mathrm{C}$ temperature, $\mathrm{C}$ mineralization rate was 0.034 in chemical fertilizer amended soil and 0.031 in INM treatment, respectively (Figure 1(c) \& 1(d)). High temperature increased C mineralization by $41 \%$ in chemical fertilizer treatment compared to INM practice. Carbon mineralization in INM treatment was low as microbial activity significantly reduced by high temperature in saline soil, which was proved at the latter part of this study. In general, microbial activity and soil nutrients are low in saline soil compared to non-saline soils (Rietz \& Haynes 2003). Several reports also proved that salinity decreases $\mathrm{C}$ mineralization from soil organic sources (Walpola \& Arunakumara 2010; Yuan et al. 2007).

\section{NITROGEN MINERALIZATION}

Initial soil total $\mathrm{N}(\%)$ content was significantly high in terrace soil $(0.12 \pm 0.003)$ compared to saline soil $(0.05 \pm 0.003)$ and in between two nutrient management practices; it was high in INM treatment as compared to chemical fertilizer amended soil. Application of cow dung in the soil (equivalent to $3 \mathrm{t} \mathrm{ha}^{-1}$ at dry weight basis)

TABLE 1. Initial soil biochemical properties of terrace and saline soil

\begin{tabular}{lcc}
\hline Properties & Saline soil & Grey terrace soil \\
\hline Texture & sandy loam & clay loam \\
Soil pH & 7.8 & 6.8 \\
Soil Ec & 6.0 & $<2$ \\
Organic carbon & 0.67 & 1.51 \\
Total N (\%) & 0.05 & 0.13 \\
Available P (ppm) & 3.20 & 20 \\
Exchangeable K $(\mathrm{ppm})$ & 58 & 47 \\
Total bacteria & $1.2 \times 10^{7}$ & $5 \times 10^{7}$ \\
Total fungus & $3.5 \times 10^{3}$ & $3 \times 10^{3}$ \\
Total actinomycetes & $3.4 \times 10^{3}$ & $2.5 \times 10^{2}$ \\
Free living $\mathrm{N}_{2}$ fixing bacteria & $7 \times 10^{4}$ & $3.5 \times 10^{5}$ \\
Phosphate solubilizing Bacteria & $4.2 \times 10^{4}$ & $3.7 \times 10^{5}$ \\
\hline
\end{tabular}



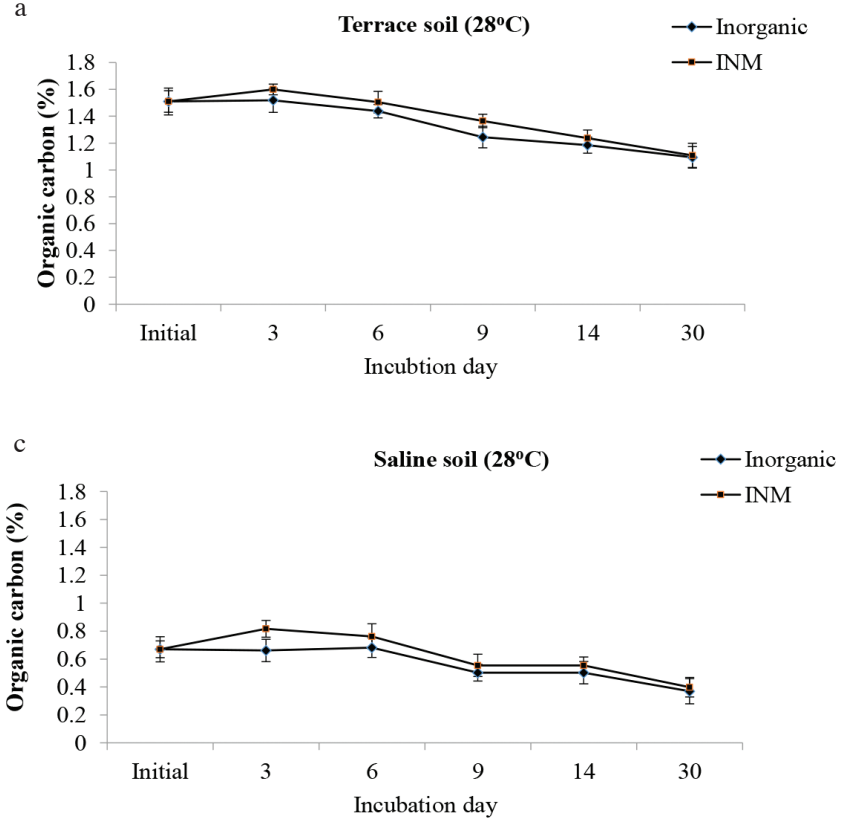
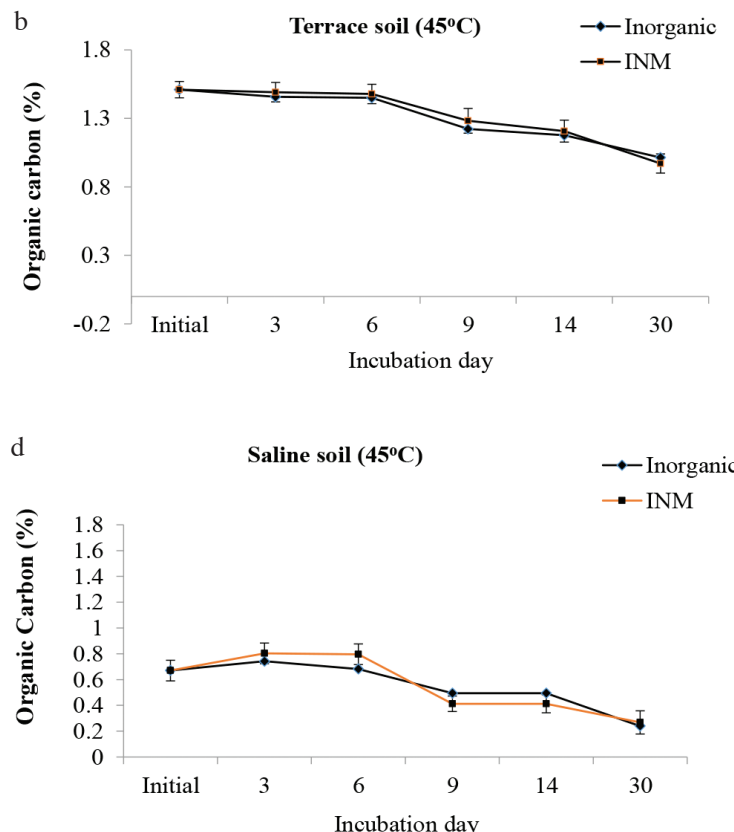

FIGURE 1. Effect of temperature and nutrient management practices on $\mathrm{C}$ mineralization in terrace and saline soils

TABLE 2. Effect of temperature and nutrient management practices on $\mathrm{C}$ mineralization rate $\left(\mathrm{r}=\mathrm{gm} \mathrm{C}\right.$ soil $\left.\mathrm{kg}^{-1} \mathrm{day}^{-1}\right)$ in terrace and saline soil

\begin{tabular}{ccccc}
\hline \multirow{2}{*}{ Soil type } & \multicolumn{2}{c}{ Temp $28^{\circ} \mathrm{C}$} & \multicolumn{2}{c}{ Temp 45 C } \\
\cline { 2 - 5 } & Chemical fertilizer & INM & Chemical fertilizer & INM \\
\hline Terrace soil & 0.011 & 0.010 & 0.013 & 0.015 \\
Saline soil & 0.020 & 0.017 & 0.034 & 0.031 \\
\hline
\end{tabular}

increased soil total $\mathrm{N}(\%)$ in INM treatment. The TN was $0.14 \pm 0.001$ and $0.07 \pm 0.005$ for INM treatment in terrace and saline soils, respectively. Alike $\mathrm{C}$ mineralization, $\mathrm{NH}_{4}^{+}-\mathrm{N}$ mineralization differed with soil type (Table 3 ). There were significant treatment and interaction effects (temperature $x$ fertilizer management practices) for $\mathrm{NH}_{4}^{+}-\mathrm{N}$ mineralization in both the soils. At normal temperature $\left(28^{\circ} \mathrm{C}\right)$ in terrace soil, significantly higher $\mathrm{NH}_{4}^{+}-\mathrm{N}$ mineralization took place from chemical fertilizer amended soil compared to INM treatment. Thangarajan et al. (2015) also reported high mineral $\mathrm{N}$ concentration in urea treatments than in organic $\mathrm{N}$ sources. In this temperature, the highest $\mathrm{NH}_{4}{ }^{+} \mathrm{N}$ mineralization (31.5 ppm) was found at day 3 and then declined sharply. However, in the same soil, high temperature $\left(45^{\circ} \mathrm{C}\right)$ induced $\mathrm{NH}_{4}-\mathrm{N}$ mineralization in INM treatment compared to chemical fertilizer amended soil. Application of organic materials increases soil $\mathrm{N}$ mineralization potential (Benitez et al. 2003) of any soil, although it mainly increases due to high temperature associated with increased initial soil microbial activities (Joergensen et al. 1990). It was proved that urease activity increases with increase in temperature (Suter et al.2011), and urease is the prerequisite for $\mathrm{NH}_{4}^{+}-\mathrm{N}$ mineralization.

In saline soil irrespective of fertilizer management, high temperature significantly induced (about 3 fold)
$\mathrm{NH}_{4}{ }^{+} \mathrm{N}$ mineralization compared to normal temperature $\left(28^{\circ} \mathrm{C}\right)$. In between two fertilizer practices, $\mathrm{NH}_{4}{ }^{+} \mathrm{N}$ mineralization was high in chemical fertilizer treatment. The highest $\mathrm{NH}_{4}^{+}-\mathrm{N}$ mineralization (80.97 ppm) was found at day 9 and then declined sharply. The mineralization of $\mathrm{N}$ in salt-affected soils is a subject of much controversy because of salt induced non-biological ammonification (Thangarajan et al. 2015). However, our recent findings strongly showed that high temperature increased $\mathrm{NH}_{4}{ }^{+}-\mathrm{N}$ mineralization in chemical fertilizer applied saline soil (Table 3).

\section{PHOSPHORUS MINERALIZATION}

Phosphorus availability in wetland condition is largely controlled by chemical equilibria in soils (Richardson \& Marshall 1986), although temperature and moisture play an important role in its mineralization. In the present study, soil moisture was in saturated condition and showed significant interaction effect between temperature and nutrient management practices for $\mathrm{P}$ mineralization in both the soils. Initial soil available $\mathrm{P}$ was higher in terrace soil compared to saline soil (Table 4). High temperature significantly enhanced $\mathrm{P}$ mineralization in INM compared to chemical fertilizer amended treatments. Phosphorus mineralization from organic sources increases with 
TABLE 3. Effect of temperature and nutrient management practices on $\mathrm{NH}_{4}^{+}-\mathrm{N}(\mathrm{ppm})$ mineralization in terrace and saline soil

\begin{tabular}{|c|c|c|c|c|c|c|c|c|}
\hline \multirow{3}{*}{$\begin{array}{c}\text { Incubation } \\
\text { day }\end{array}$} & \multicolumn{4}{|c|}{ Terrace soil } & \multicolumn{4}{|c|}{ Saline soil } \\
\hline & \multicolumn{2}{|c|}{ Temp $28^{\circ} \mathrm{C}$} & \multicolumn{2}{|c|}{ Temp $45^{\circ} \mathrm{C}$} & \multicolumn{2}{|c|}{ Temp $28^{\circ} \mathrm{C}$} & \multicolumn{2}{|c|}{ Temp $45^{\circ} \mathrm{C}$} \\
\hline & $\begin{array}{l}\text { Chemical } \\
\text { fertilizer }\end{array}$ & INM & $\begin{array}{l}\text { Chemical } \\
\text { fertilizer }\end{array}$ & INM & $\begin{array}{l}\text { Chemical } \\
\text { fertilizer }\end{array}$ & INM & $\begin{array}{l}\text { Chemical } \\
\text { fertilizer }\end{array}$ & INM \\
\hline Day 3 & $31.5 \mathrm{ed}$ & 29.1ed & $26.3 \mathrm{e}$ & $24.9 \mathrm{e}$ & $23.45 \mathrm{e}$ & $22.05 \mathrm{e}$ & $68.95 \mathrm{ab}$ & $36.4 \mathrm{~d}$ \\
\hline Day 6 & $26.5 \mathrm{e}$ & $24.9 \mathrm{e}$ & $23.1 \mathrm{e}$ & $28.4 \mathrm{ed}$ & $25.55 \mathrm{e}$ & $22.05 \mathrm{e}$ & $51.80 \mathrm{c}$ & $53.2 \mathrm{c}$ \\
\hline Day 9 & $24.3 \mathrm{e}$ & $22.9 \mathrm{e}$ & $23.0 \mathrm{e}$ & $24.5 \mathrm{e}$ & $25.55 \mathrm{e}$ & $18.43 \mathrm{ef}$ & $80.97 \mathrm{a}$ & $74.67 \mathrm{ab}$ \\
\hline Day 14 & $21.7 \mathrm{ef}$ & $18.4 \mathrm{ef}$ & $22.4 \mathrm{e}$ & $23.1 \mathrm{e}$ & $23.10 \mathrm{e}$ & $23.80 \mathrm{e}$ & 69.30ab & $61.95 \mathrm{~b}$ \\
\hline Day 30 & $14.7 \mathrm{f}$ & $17.5 \mathrm{f}$ & $20.1 \mathrm{ef}$ & $22.4 \mathrm{e}$ & 20.77 ef & $18.55 \mathrm{ef}$ & $26.95 \mathrm{e}$ & $40.95 \mathrm{~d}$ \\
\hline
\end{tabular}

Means followed by the same letter are not statistical significant

TABLE 4. Effect of temperature and nutrient management practices on available P (ppm) in terrace and saline soil (standard error of 3 replications)

\begin{tabular}{|c|c|c|c|c|c|c|c|c|}
\hline \multirow{3}{*}{$\begin{array}{l}\text { Incubation } \\
\text { day }\end{array}$} & \multicolumn{4}{|c|}{ Terrace soil } & \multicolumn{4}{|c|}{ Saline soil } \\
\hline & \multicolumn{2}{|c|}{ Temp $28^{\circ} \mathrm{C}$} & \multicolumn{2}{|c|}{ Temp $45^{\circ} \mathrm{C}$} & \multicolumn{2}{|c|}{ Temp $28^{\circ} \mathrm{C}$} & \multicolumn{2}{|c|}{ Temp $45^{\circ} \mathrm{C}$} \\
\hline & $\begin{array}{l}\text { Chemical } \\
\text { fertilizer }\end{array}$ & INM & $\begin{array}{l}\text { Chemical } \\
\text { fertilizer }\end{array}$ & INM & $\begin{array}{l}\text { Chemical } \\
\text { fertilizer }\end{array}$ & INM & $\begin{array}{l}\text { Chemical } \\
\text { fertilizer }\end{array}$ & INM \\
\hline Day 3 & $21.16 \pm 0.23$ & $23.14 \pm 0.28$ & $22.11 \pm 0.86$ & $25.99 \pm 0.39$ & $3.22 \pm 0.44$ & $4.23 \pm 0.16$ & $3.41 \pm 0.41$ & $3.79 \pm 0.21$ \\
\hline Day 6 & $22.15 \pm 0.21$ & $24.31 \pm 0.23$ & $21.67 \pm 0.64$ & $28.60 \pm 0.31$ & $3.64 \pm 0.22$ & $5.88 \pm 0.94$ & $4.53 \pm 0.18$ & $4.39 \pm 0.23$ \\
\hline Day 9 & $22.13 \pm 0.38$ & $25.99 \pm 0.20$ & $20.87 \pm 0.62$ & $30.46 \pm 0.18$ & $3.90 \pm 0.12$ & $6.26 \pm 0.06$ & $5.14 \pm 0.46$ & $6.35 \pm 0.05$ \\
\hline Day 14 & $18.78 \pm 1.08$ & $21.01 \pm 0.73$ & $17.85 \pm 0.28$ & $19.25 \pm 1.25$ & $3.83 \pm 0.29$ & $4.66 \pm 0.10$ & $3.95 \pm 0.08$ & $4.63 \pm 0.47$ \\
\hline Day 30 & $14.04 \pm 1.37$ & $16.11 \pm 0.87$ & $13.36 \pm 0.83$ & $16.02 \pm 0.79$ & $3.67 \pm 0.22$ & $3.97 \pm 0.32$ & $4.12 \pm 0.26$ & $3.53 \pm 0.25$ \\
\hline
\end{tabular}

increasing temperature (Thompson \& Black 1947; Whalen et al.2001) which is in agreement with our present findings. In INM treatment, after 9 days of incubation, the highest $\mathrm{P}$ mineralization $(25.99 \mathrm{ppm})$ was found at $28^{\circ} \mathrm{C}$ and at $45^{\circ} \mathrm{C}$ temperature; it was $30.46 \mathrm{ppm}$ and then declined sharply. Grierson et al. (1998) also reported that increase in incubation temperature from $15^{\circ} \mathrm{C}$ to $38^{\circ} \mathrm{C}$ increased $\mathrm{P}$ mineralization from $13 \%$ to $53 \%$. In case of inorganic fertilizer treatment, a gradual decrease in P mineralization occurred with both imposed temperatures.

In the saline soil, nutrient management practices and temperature also affected P mineralization. Similarly, to terrace soil, $\mathrm{P}$ mineralization was high in INM treatment. At $28^{\circ} \mathrm{C}$ temperature, $\mathrm{P}$ mineralization was high with INM treatment (Table 4$)$. The highest available P (6.26 ppm) was found in this treatment at 9 days of incubation and then declined sharply. In chemical fertilizer treatment, $\mathrm{P}$ mineralization followed linear pattern. At $45^{\circ} \mathrm{C}$ temperature the highest available $\mathrm{P}(6.35 \mathrm{ppm})$ was found in INM treatment at 9 days of incubation.

\section{POTASSIUM MINERALIZATION}

Potassium release in soils is largely controlled by physical adsorption of clay particles (Mengel 1982; Scheffer \& Schachtschabel 1989). However, high temperature and biological activity also increases K release (Sparks \&
Huang 1985). In our study, initial K content was high in saline soil compared to terrace soil (Table 5). There was significant treatment effect and interaction effect (temperature $\times$ nutrient management practices) for $\mathrm{K}$ mineralization in both the soils. In terrace soil, treatment effect was significant up to 14 days of incubation. In this soil at $28^{\circ} \mathrm{C}$ temperature, $\mathrm{K}$ mineralization was higher with chemical fertilizer amended soil compared to INM treatment. The highest soil exchangeable K (86 ppm) was found at 6 days in chemical fertilizer treatment and then declined sharply and mineralization became stable at 14 days. At the initial stage, availability of $\mathrm{K}$ from chemical fertilizer may have induced soil $\mathrm{K}$ in this treatment. In INM treatment, it gradually decreased up to 30 days. Higher amount of $\mathrm{K}$ mineralization was found in INM treatment at $45^{\circ} \mathrm{C}$ temperature and it decreased gradually up to 30 days. The highest exchangeable (K, 70.1 ppm) was found in INM treatment at 3 days of incubation.

In saline soil, treatment and its interaction effect was significant only up to 6 days of incubation period. In this soil, higher $\mathrm{K}$ mineralization was found in INM treatment up to 9 days and then decreased gradually. In chemical fertilizer treatment, $\mathrm{K}$ mineralization was high only up to 3 days and it declined sharply at 14 days. At $45^{\circ} \mathrm{C}$ temperature, no differences were found for $\mathrm{K}$ mineralization with both the nutrient management practices. This may be due to high temperatures reduced 
TABLE 5. Effect of temperature and nutrient management practices on exchangeable $\mathrm{K}$ (ppm) mineralization in terrace and saline soil (standard error of 3 replications)

\begin{tabular}{|c|c|c|c|c|c|c|c|c|}
\hline \multirow{3}{*}{$\begin{array}{c}\text { Incubation } \\
\text { day }\end{array}$} & \multicolumn{4}{|c|}{ Terrace soil } & \multicolumn{4}{|c|}{ Saline soil } \\
\hline & \multicolumn{2}{|c|}{ Temp $28^{\circ} \mathrm{C}$} & \multicolumn{2}{|c|}{ Temp $45^{\circ} \mathrm{C}$} & \multicolumn{2}{|c|}{ Temp $28^{\circ} \mathrm{C}$} & \multicolumn{2}{|c|}{ Temp $45^{\circ} \mathrm{C}$} \\
\hline & $\begin{array}{l}\text { Chemical } \\
\text { fertilizer }\end{array}$ & INM & $\begin{array}{l}\text { Chemical } \\
\text { fertilizer }\end{array}$ & INM & $\begin{array}{l}\text { Chemical } \\
\text { fertilizer }\end{array}$ & INM & $\begin{array}{l}\text { Chemical } \\
\text { fertilizer }\end{array}$ & INM \\
\hline Day 3 & $59.1 \pm 3.0$ & $64.1 \pm 6.7$ & $55.1 \pm 6.2$ & $70.1 \pm 3.4$ & $89.0 \pm 6.0$ & $96.9 \pm 3.4$ & $90.9 \pm 2.6$ & $94.9 \pm 3.0$ \\
\hline Day 6 & $86.0 \pm 3.1$ & $55.1 \pm 4.6$ & $45.2 \pm 1.7$ & $54.1 \pm 4.2$ & $45.2 \pm 1.7$ & $90.9 \pm 1.6$ & $98.9 \pm 3.0$ & $93.9 \pm 5.1$ \\
\hline Day 9 & $50.2 \pm 3.0$ & $47.2 \pm 2.4$ & $44.2 \pm 1.5$ & $54.6 \pm 1.5$ & $78.5 \pm 1.4$ & $90.4 \pm 1.6$ & $81.5 \pm 1.5$ & $78.5 \pm 1.5$ \\
\hline Day 14 & $27.3 \pm 3.4$ & $39.2 \pm 1.6$ & $32.3 \pm 3.0$ & $38.2 \pm 4.3$ & $24.3 \pm 5.2$ & $41.2 \pm 4.7$ & $51.2 \pm 1.2$ & $45.2 \pm 4.2$ \\
\hline Day 30 & $25.3 \pm 2.3$ & $26.3 \pm 1.7$ & $26.3 \pm 1.3$ & $30.3 \pm 4.2$ & $38.2 \pm 2.1$ & $45.2 \pm 3.4$ & $42.2 \pm 1.7$ & $40.2 \pm 3.2$ \\
\hline
\end{tabular}

microbial populations in sandy soils (Table 5). At this temperature, $\mathrm{K}$ mineralization was high up to 6 days and then gradually declined and at 14 days of incubation period $\mathrm{K}$ mineralization became stable.

\section{SOIL BIOLOGICAL PROCESS}

The significant effect of temperature and nutrient management practices for soil biological process was recorded, although the pattern of population changes in response to temperature was not similar for bacteria, actinomycetes and fungi. The highest population change was found in bacteria. Same trend was reported by Biederbeck and Campbell (1973) that the extent of growth response was the highest for bacteria and the least for the actinomycetes population.

\section{BACTERIAL POPULATION}

Bacteria population was higher in terrace soil compared to saline soil, which might be due to soil texture, salinity and organic matter content. Bacterial population is affected by particle size and the higher population is found with finer textured soil compared to coarse texture (Mohammad et al. 2015). In terrace soil at $28^{\circ} \mathrm{C}$ temperature, population declined sharply after 14 days of incubation. At $45^{\circ} \mathrm{C}$, initial bacterial population was more with INM treatment that decreased after 9 days of incubation period and followed similar pattern for both the nutrient management practices. High temperature may increase initial population growth with INM treatment and its decreasing trend proved lack of available substrates. The highest bacteria population $\left(4.2-4.4 \times 10^{8} \mathrm{Cfu} \mathrm{g}^{-1}\right.$ soil) was found at day 9 with high temperature under INM treatment (Table 6).

In saline soil at $28^{\circ} \mathrm{C}$, decrease in bacterial population followed similar patterns with both the nutrient management practices (Table 6). The highest bacterial population (1.1-3.9 $\times 10^{7} \mathrm{Cfu} \mathrm{g}^{-1}$ soil) was found at 3 days of incubation period and then decreased gradually up to 9 days. A slight increase in population was found on day 14 , and again declined at 30 days of incubation period. At $458^{\circ} \mathrm{C}$, bacterial population was low (4.2-4.5 $\times 10^{6} \mathrm{Cfu} \mathrm{g}^{-1}$ soil) at 3 days of incubation compared to $28^{\circ} \mathrm{C}$ temperature. In chemical fertilizer treatment, $3.4 \times$ $10^{5} \mathrm{Cfu} \mathrm{g}^{-1}$ bacteria population maintained up to 9 days of incubation and then declined. In INM treatment similar population maintained up to 14 days of incubation period. Organic nutrient sources might have supported bacterial growth slightly longer than chemical fertilizers.

TABLE 6. Effect of temperature and nutrient management practices on soil bacteria population $\left(\mathrm{Cfu} \mathrm{g}^{-1}\right.$ soil) in terrace and saline soil

\begin{tabular}{ccccccccc}
\hline & \multicolumn{9}{c}{ Terrace soil } \\
\cline { 2 - 9 } $\begin{array}{c}\text { Incubation } \\
\text { day }\end{array}$ & \multicolumn{2}{c}{ Temp 28 C } & \multicolumn{2}{c}{ Temp $45^{\circ} \mathrm{C}$} & \multicolumn{2}{c}{ Temp $28^{\circ} \mathrm{C}$} & \multicolumn{2}{c}{ Temp $45^{\circ} \mathrm{C}$} \\
\cline { 2 - 9 } & $\begin{array}{c}\text { Chemical } \\
\text { fertilizer }\end{array}$ & INM & $\begin{array}{c}\text { Chemical } \\
\text { fertilizer }\end{array}$ & INM & $\begin{array}{c}\text { Chemical } \\
\text { fertilizer }\end{array}$ & INM & $\begin{array}{c}\text { Chemical } \\
\text { fertilizer }\end{array}$ & INM \\
\hline Day 3 & $4.8 \times 10^{7} \mathrm{~b}$ & $5.0 \times 10^{7} \mathrm{~b}$ & $6.0 \times 10^{6} \mathrm{c}$ & $3.6 \times 10^{7} \mathrm{~b}$ & $1.1 \times 10^{7} \mathrm{~b}$ & $3.9 \times 10^{7} \mathrm{~b}$ & $4.2 \times 10^{6} \mathrm{c}$ & $4.5 \times 10^{6} \mathrm{c}$ \\
Day 6 & $3.6 \times 10^{7} \mathrm{~b}$ & $3.5 \times 10^{7} \mathrm{~b}$ & $4.0 \times 10^{6} \mathrm{~b}$ & $7.2 \times 10^{6} \mathrm{c}$ & $3.1 \times 10^{5} \mathrm{~d}$ & $4.2 \times 10^{4} \mathrm{e}$ & $4.4 \times 10^{5} \mathrm{~d}$ & $6.2 \times 10^{4} \mathrm{e}$ \\
Day 9 & $6.2 \times 10^{7} \mathrm{~b}$ & $7.2 \times 10^{7} \mathrm{~b}$ & $4.4 \times 10^{8} \mathrm{a}$ & $4.2 \times 10^{8} \mathrm{a}$ & $2.8 \times 10^{5} \mathrm{~d}$ & $3.2 \times 10^{5} \mathrm{~d}$ & $3.4 \times 10^{5} \mathrm{~d}$ & $2.2 \times 10^{5} \mathrm{~d}$ \\
Day 14 & $2.9 \times 10^{7} \mathrm{~b}$ & $3.6 \times 10^{7} \mathrm{~b}$ & $3.0 \times 10^{5} \mathrm{~d}$ & $1.2 \times 10^{5} \mathrm{~d}$ & $5.1 \times 10^{6} \mathrm{c}$ & $2.5 \times 10^{6} \mathrm{c}$ & $4.4 \times 10^{4} \mathrm{e}$ & $2.9 \times 10^{5} \mathrm{~d}$ \\
Day 30 & $9.3 \times 10^{4} \mathrm{e}$ & $5.8 \times 10^{4} \mathrm{e}$ & $2.7 \times 10^{4} \mathrm{e}$ & $4.1 \times 10^{4} \mathrm{e}$ & $1.2 \times 10^{4} \mathrm{e}$ & $1.5 \times 10^{4} \mathrm{e}$ & $1.0 \times 10^{4} \mathrm{e}$ & $2.7 \times 10^{4} \mathrm{e}$ \\
\hline
\end{tabular}

Means followed by the same letter are not statistical significant 
TABLE 7. Effect of temperature and nutrient management practices on fungus population (Cfu $\mathrm{g}^{-1}$ soil) in terrace and saline soil

\begin{tabular}{|c|c|c|c|c|c|c|c|c|}
\hline \multirow{3}{*}{$\begin{array}{c}\text { Incubation } \\
\text { day }\end{array}$} & \multicolumn{4}{|c|}{ Terrace soil } & \multicolumn{4}{|c|}{ Saline soil } \\
\hline & \multicolumn{2}{|c|}{ Temp $28^{\circ} \mathrm{C}$} & \multicolumn{2}{|c|}{ Temp $45^{\circ} \mathrm{C}$} & \multicolumn{2}{|c|}{ Temp $28^{\circ} \mathrm{C}$} & \multicolumn{2}{|c|}{ Temp $45^{\circ} \mathrm{C}$} \\
\hline & $\begin{array}{l}\text { Chemical } \\
\text { fertilizer }\end{array}$ & INM & $\begin{array}{l}\text { Chemical } \\
\text { fertilizer }\end{array}$ & INM & $\begin{array}{l}\text { Chemical } \\
\text { fertilizer }\end{array}$ & INM & $\begin{array}{l}\text { Chemical } \\
\text { fertilizer }\end{array}$ & INM \\
\hline Day 3 & $2.3 \times 10^{2} \mathrm{c}$ & $2.2 \times 10^{2} \mathrm{c}$ & $1.5 \times 10^{2} \mathrm{c}$ & $4.4 \times 10^{2} \mathrm{c}$ & $3.4 \times 10^{3} \mathrm{~b}$ & $2.0 \times 10^{3} \mathrm{~b}$ & $2.5 \times 10^{4} \mathrm{a}$ & $2.8 \times 10^{4} \mathrm{a}$ \\
\hline Day 6 & $6.1 \times 10^{2} \mathrm{c}$ & $4.3 \times 10^{2} \mathrm{c}$ & $3.6 \times 10^{2} \mathrm{c}$ & $2.8 \times 10^{2} \mathrm{c}$ & $1.9 \times 10^{3} \mathrm{~b}$ & $1.7 \times 10^{3} \mathrm{~b}$ & $5.1 \times 10^{2} \mathrm{c}$ & $2.5 \times 10^{2} \mathrm{c}$ \\
\hline Day 9 & $2.1 \times 10^{2} \mathrm{c}$ & $2.3 \times 10^{2} \mathrm{c}$ & $1.4 \times 10^{2} \mathrm{c}$ & $6.3 \times 10^{3} \mathrm{~b}$ & $1.2 \times 10^{2} \mathrm{c}$ & $1.1 \times 10^{2} \mathrm{c}$ & $1.0 \times 10^{2} \mathrm{c}$ & $1.2 \times 10^{2} \mathrm{c}$ \\
\hline Day 14 & $2.0 \times 10^{2} \mathrm{c}$ & $2.2 \times 10^{2} \mathrm{c}$ & $1.3 \times 10^{2} \mathrm{c}$ & $2.4 \times 10^{2} \mathrm{c}$ & $1.4 \times 10^{2} \mathrm{c}$ & $1.2 \times 10^{2} \mathrm{c}$ & $1.2 \times 10^{2} \mathrm{c}$ & $1.1 \times 10^{2} \mathrm{c}$ \\
\hline Day 30 & $1.3 \times 10^{2} \mathrm{c}$ & $1.2 \times 10^{2} \mathrm{c}$ & $1.1 \times 10^{2} \mathrm{c}$ & $1.0 \times 10^{2} \mathrm{c}$ & $1.2 \times 10^{2} \mathrm{c}$ & $1.5 \times 10^{2} \mathrm{c}$ & $1.1 \times 10^{2} \mathrm{c}$ & $1.1 \times 10^{2} \mathrm{c}$ \\
\hline
\end{tabular}

Means followed by the same letter are not statistical significant

\section{FUNGUS POPULATION}

Fungus population was higher in saline soil compared to terrace soil (Table 7). Significant effect of temperature and nutrient management practices was found on fungus population only up to 14 days of incubation. In saline soil, high temperature enhanced fungus population (2.5-2.8 $\times$ $10^{4} \mathrm{Cfu} \mathrm{g}^{-1}$ soil) with INM treatment only up to 3 days of incubation period and then decreased linearly.

\section{ACTINOMYCETES POPULATION}

There was no significant interaction effect of temperature and nutrient management practices on actinomycetes population for both the soils (Table 8). Actinomycetes population was higher in saline soil compared to terrace soil. At $28^{\circ} \mathrm{C}$ temperature, soil actinomycetes population $\left(1.7-2.0 \times 10^{3} \mathrm{Cfu}^{-1}\right)$ maintained until day 6 and after that it followed linear growth pattern. High temperature increases its population $\left(2.5-2.8 \times 10^{4} \mathrm{Cfu} \mathrm{g}^{-1}\right.$ soil $)$ in saline soil only at 3 days of incubation and then decreased in linear pattern. However, the study report of Biederbeck and Campbell (1973) showed that actinomycetes were more resistant to temperature than bacteria and fungus community.

\section{FREE LIVING $\mathrm{N}_{2}$ FIXING AND PSB POPULATION}

Free-living $\mathrm{N}_{2}$ fixing and PSB population are beneficial soil bacteria and directly involve for bio-available $\mathrm{N}$ and $\mathrm{P}$ nutrition (Biswas et al. 2000; Naher et al. 2013; Panhwar et al.2014). Irrespective of soils and nutrient management practices, $\mathrm{N}_{2}$ fixing bacteria population was high in INM treatments (Figure 2). At $28^{\circ} \mathrm{C}$ temperature in terrace soil, no significant effect of nutrient management practices was found on free-living $\mathrm{N}_{2}$ fixing bacteria population. In this soil at $45^{\circ} \mathrm{C}$ temperature, $\mathrm{N}_{2}$ fixing bacteria survived only up to 14 days of incubation. High temperature affected soil microbe-microbe interactions directly (Classen et al. 2015) and this could be more sensitive for free-living $\mathrm{N}_{2}$ fixing bacteria. In saline soil, $\mathrm{N}_{2}$ fixing bacteria population was found only up to 9 days of incubation, which indicates that free living $\mathrm{N}_{2}$ fixing bacteria are more sensitive to constant soil salinity in artificial condition. There was significant effect of temperature and nutrient management practices on phosphate solubilizing bacteria population in saline soil (Figure 3). In terrace soil, high PSB population was found at 3 days of incubation and then declined. Whereas, in saline soil there a linear declined of PSB population was recorded.

TABLE 8. Effect of temperature and nutrient management practices on actinomycetes population $\left(\mathrm{Cfu} \mathrm{g}^{-1}\right.$ soil) in terrace and saline soil

\begin{tabular}{|c|c|c|c|c|c|c|c|c|}
\hline \multirow{3}{*}{$\begin{array}{c}\text { Incubation } \\
\text { day }\end{array}$} & \multicolumn{4}{|c|}{ Terrace soil } & \multicolumn{2}{|c|}{ Saline soil } & & \\
\hline & \multicolumn{2}{|c|}{ Temp $28^{\circ} \mathrm{C}$} & \multicolumn{2}{|c|}{ Temp $45^{\circ} \mathrm{C}$} & \multicolumn{2}{|c|}{ Temp $28^{\circ} \mathrm{C}$} & \multicolumn{2}{|c|}{ Temp $45^{\circ} \mathrm{C}$} \\
\hline & $\begin{array}{l}\text { Chemical } \\
\text { fertilizer }\end{array}$ & INM & $\begin{array}{l}\text { Chemical } \\
\text { fertilizer }\end{array}$ & INM & $\begin{array}{l}\text { Chemical } \\
\text { fertilizer }\end{array}$ & INM & $\begin{array}{l}\text { Chemical } \\
\text { fertilizer }\end{array}$ & INM \\
\hline Day 3 & $2.3 \times 10^{2} \mathrm{c}$ & $2.2 \times 10^{2} \mathrm{c}$ & $1.5 \times 10^{2} \mathrm{c}$ & $4.4 \times 10^{2} \mathrm{c}$ & $3.4 \times 10^{3} \mathrm{~b}$ & $2.0 \times 10^{3} \mathrm{~b}$ & $2.5 \times 10^{4} \mathrm{a}$ & $2.8 \times 10^{4} a$ \\
\hline Day 6 & $6.1 \times 10^{2} \mathrm{c}$ & $4.3 \times 10^{2} \mathrm{c}$ & $3.6 \times 10^{2} \mathrm{c}$ & $2.8 \times 10^{2} \mathrm{c}$ & $1.9 \times 10^{3} b$ & $1.7 \times 10^{3} b$ & $5.1 \times 10^{2} \mathrm{c}$ & $2.5 \times 10^{2} \mathrm{c}$ \\
\hline Day 9 & $2.1 \times 10^{2} \mathrm{c}$ & $2.3 \times 10^{2} \mathrm{c}$ & $1.4 \times 10^{2} \mathrm{c}$ & $6.3 \times 10^{3} \mathrm{~b}$ & $1.2 \times 10^{2} \mathrm{c}$ & $1.1 \times 10^{2} \mathrm{c}$ & $1.0 \times 10^{2} \mathrm{c}$ & $1.2 \times 10^{2} \mathrm{c}$ \\
\hline Day 14 & $2.0 \times 10^{2} \mathrm{c}$ & $2.2 \times 10^{2} \mathrm{c}$ & $1.3 \times 10^{2} \mathrm{c}$ & $2.4 \times 10^{2} \mathrm{c}$ & $1.4 \times 10^{2} \mathrm{c}$ & $1.2 \times 10^{2} \mathrm{c}$ & $1.2 \times 10^{2} \mathrm{c}$ & $1.1 \times 10^{2} \mathrm{c}$ \\
\hline Day 30 & $1.3 \times 10^{2} \mathrm{c}$ & $1.2 \times 10^{2} \mathrm{c}$ & $1.1 \times 10^{2} \mathrm{c}$ & $1.0 \times 10^{2} \mathrm{c}$ & $1.2 \times 10^{2} \mathrm{c}$ & $1.5 \times 10^{2} \mathrm{c}$ & $1.1 \times 10^{2} \mathrm{c}$ & $1.1 \times 10^{2} \mathrm{c}$ \\
\hline
\end{tabular}

Means followed by the same letter are not statistical significant 

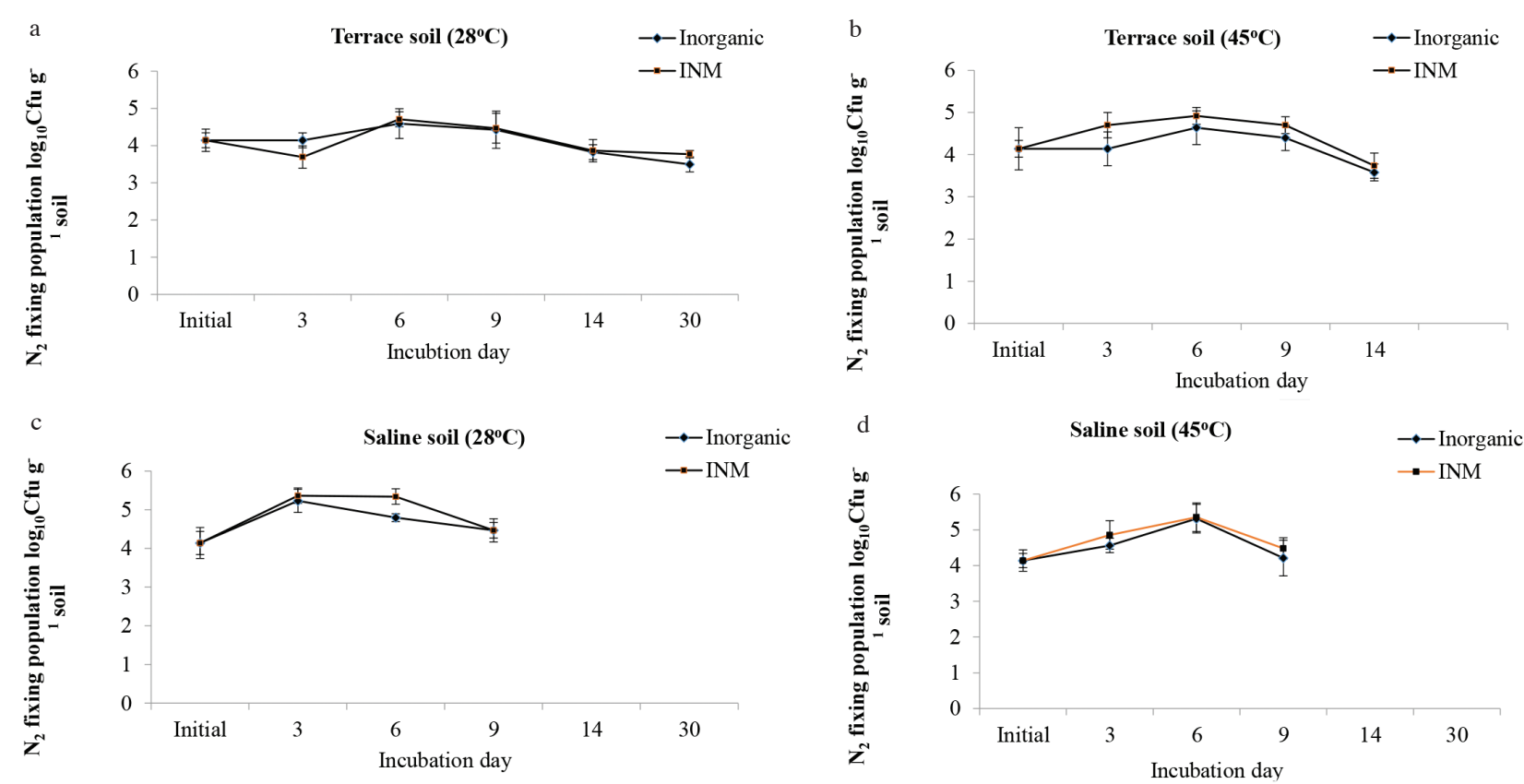

FIGURE 2. Effect of temperature and nutrient management practices on $\mathrm{N}_{2}$ fixing bacteria population in terrace and saline soil
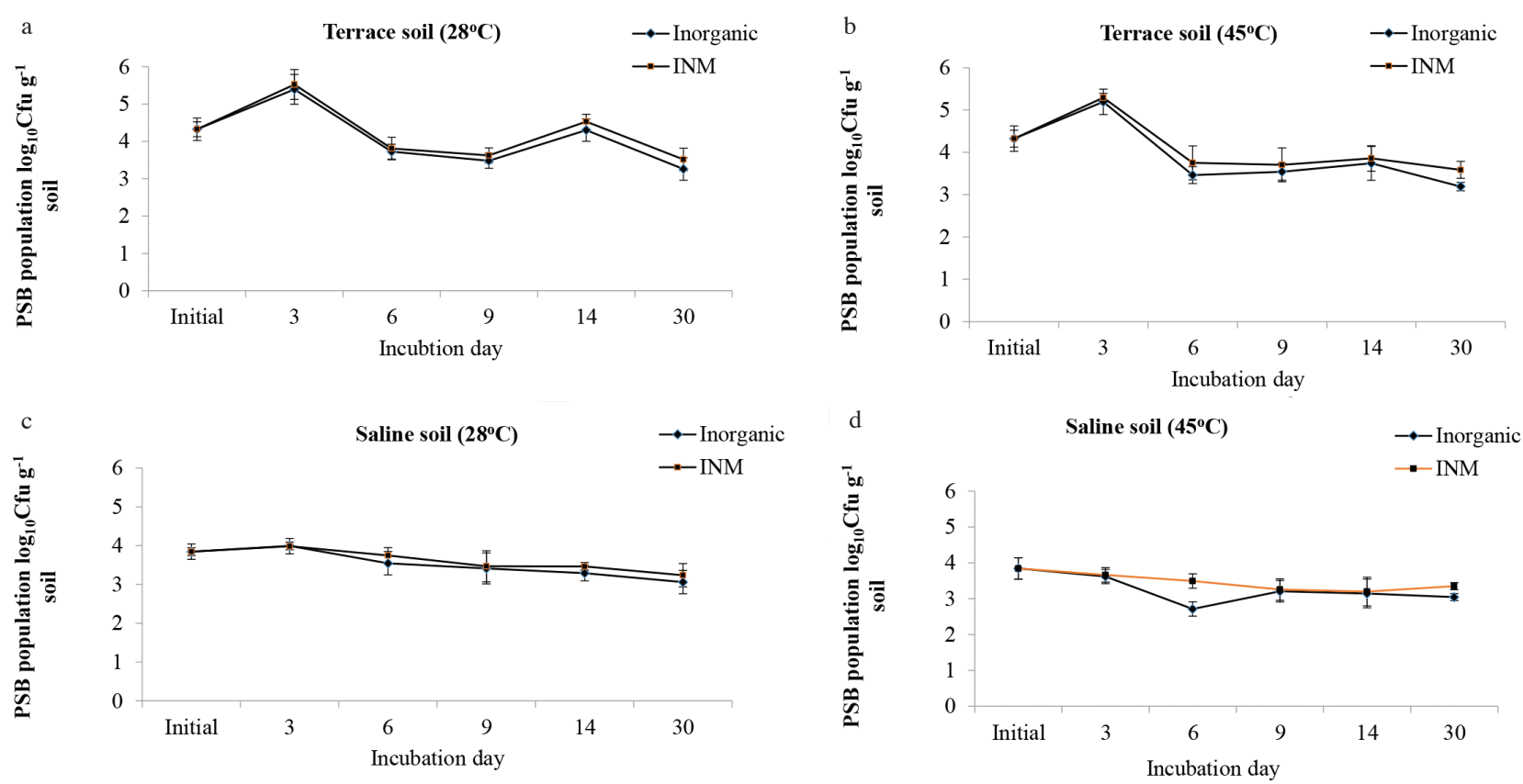

FIGURE 3. Effect of temperature and nutrient management practices on PSB population in terrace and saline soil

\section{CONCLUSION}

Nutrient mineralization and biology of any soil is affected by temperature, fertilizer management practices, soil texture, soil salinity and soil organic matter content. The mode of action varied according to soil type. In the present investigation, significant treatment effect and its interaction effect (temperature $\times$ nutrient management practices) was recorded for SOC, N, P, K mineralization and microbial populations for both terrace and saline soils. At high temperature, $\mathrm{SOC}$ and $\mathrm{NH}_{4}^{+}-\mathrm{N}$ mineralization rate was more with saline soil compared to terrace soil. Phosphorus mineralization was rapid at high temperature, especially in INM treatment. Potassium mineralization was high in chemical fertilizer treatment. Free-living $\mathrm{N}_{2}$ fixing bacteria were more sensitive to high temperature. Bacteria population was more affected and decreased than fungi and actinomycetes and exaggerated more in chemical fertilizer compared to INM practice. In changing climate with high temperature, INM could be a better option for saline soil management. 


\section{ACKNOWLEDGEMENTS}

Authors are grateful to Bangladesh Rice Research Institute for providing facility to do research work and CRP-II project, funded by Krishi Gobeshona Foundation for financial assistance.

\section{REFERENCES}

Allison, I., Bindoff, N., Bindschadler, R., Cox, P., de NobletDucoudre, N., England, M., Francis, J., Gruber, N., Haywood, A., Karoly, D., Kaser, G., Le Quéré, C., Lenton, T., Mann, M., McNeil, B., Pitman, A., Rahmstorf, S., Rignot, E., Schellnhuber, H.J., Schneider, S., Sherwood, S., Somerville, R., Steffen, K., Steig, E., Visbeck, M. \& Weaver, A. 2009. The Copenhagen Diagnosis 2009: Updating the World on the Latest Climate Science. Sydney, Australia: The University of New South Wales Climate Change Research Centre (CCRC).

Bárcenas-Moreno, G., Gómez-Brandón, M., Rousk, J. \& Bååth, E. 2009. Adaptation of soil microbial communities to temperature: Comparison of fungi and bacteria in a laboratory experiment. Global Change Biol. 15: 2950-2957.

Bekku, Y.S., Nakatsubo, T., Kume, A. \& Koizumi, H. 2004. Soil microbial biomass, respiration rate, and temperature dependence on a successional glacier foreland in Nylesund, Svalbard. Arct. Antarct. Alp. Res. 36(4): 395-399.

Benitez, C., Tejada, M. \& Gonzalez, J. 2003. Kinetics of the mineralization of nitrogen in a pig slurry compost applied to soils. Compost Sci. Util. 11: 72-80.

Benton, J.J. 2001. Laboratory Guide for Conducting Soil Tests and Plant Analysis. New York: CRC Press LLC. pp. 27-41.

Biederbeck, V.O. \& Campbell, C.A. 1973. Soil microbial activity as influenced by temperature trends and fluctuations. Can. J. Soil Sci. 53: 363-376.

Birgander, J., Reischke, S., Jones, D.L. \& Rousk, J. 2013. Temperature adaptation of bacterial growth and 14C-glucose mineralisation in a laboratory study. Soil Biol. Biochem. 65: 294-303.

Biswas, J.C., Ladha, J.K. \& Dazzo, F.B. 2000. Rhizobia inoculation improves nutrient uptake and growth of lowland rice. Soil Sci. Soc. Am. J. 64(5): 1644-1650.

Bustamante, M.A., Paredes, C., Marhuenda-Egea, F.C., PérezEspinosa, A., Bernal, M.P. \& Moral, R. 2008. Cocomposting distillery wastes with animal manure: Carbon and nitrogen transformations and evaluation of compost stability. Chemosphere 72: 551-557.

Bremner, J.M. \& Mulvaney, C.S. 1982. Total nitrogen. In Methods of Soil Analysis, edited by Page, A.L., Miller, R.H. \& Keeny, D.R. Madison: American Society of Agronomy and Soil Science Society of America. pp. 1119-1123.

Classen, A.T., Sundqvist, M.K., Henning, J.A., Newman, G.S., Moore, J.A.M., Cregger, M.A., Moorheadand, L.C. \& Patterson, C.M. 2015. Direct and indirect effects of climate change on soil microbial and soil microbial-plant interactions: What lies ahead? Ecosphere 6(8): 1-21.

Co^te', L., Brown, S., Pare', D., Fyles, J. \& Bauhus, J. 2000. Dynamics of carbon and nitrogen mineralization in relation to stand type, stand age and soil texture in the boreal mixed wood. Soil Biol. Biochem. 32: 1079-1090.

Craine, J.M. \& Gelderman, T.M. 2010. Soil moisture controls on temperature sensitivity of soil organic carbon decomposition for a mesic grassland. Soil Biol. Biochem. 43: 455-457.

Deressa, A. 2015. Effects of soil moisture and temperature on carbon and nitrogen mineralization in grassland soils fertilized with improved cattle slurry manure with and without manure additive. J. Environ. Hum. 2(1): 2373-8324.

Grierson, P.F., Comerford, N.B. \& Jokela, E.J. 1998. Phosphorus mineralization kinetics and response of microbial phosphorus to wetting and drying in a Florida Spodosol. Soil Biol. Biochem. 30: 1323-1331.

https://earthobservatory.nasa.gov/Features/GlobalWarming/ page2.php. Accessed on June 26, 2017.

Islam, T. \& Neelim, A. 2010. Climate Change in Bangladesh: A Closer Look into Temperature and Rainfall Data. Dhaka: The University Press Limited.

Joergensen, R.G., Brookes, P.C. \& Jenkinson, D.S. 1990. Survival of the soil microbial biomass at elevated temperatures. Soil Biol. Biochem. 22: 1129-1136.

Lange, O.L. \& Green, T.G.A. 2005. Lichens show that fungi can acclimate their respiration to seasonal changes in temperature. Oecol. 142: 11-19.

Mahmud, K., Nasiruddin, K.M. \& Hassan, L. 2016. Regeneration of sugarcane variety ISD 40 against salt stress condition. Sci. Tech. 2(8): 485-491.

Murphy, J. \& Riley, J.P. 1962. A modified single solution method for the determination of phosphate in natural waters. Anal. Chim. Acta 27: 31-36.

McKinley, V.L. \& Vestal, J.R. 1984. Biokinetic analyses of adaptation and succession: Microbial activity in composting municipal sewage sludge. Appl. Environ. Microbiol. 47: 933-941.

Mengel, K. 1982. Dynamics and availability of major nutrients in soils. Adv. Soil Sci. 2: 65-131.

Mohammad, A. 2015. Assessing changes in soil microbial population with some soil physical and chemical properties. Int. J. Plant Animal Environ. Sci. 5(3): 2231-4490.

Naher, U.A., Othman, R. \& Panhwar, Q.A. 2013. Culturable total and beneficial microbial occurrences in long-term nutrient deficit wetland rice soil. Aust. J. Crop Sci. 7(12): 1848-1853.

Panhwar, Q.A., Naher, U.A., Jusop, S., Othman, R., Latif, M.D.A. \& Ismail, M.R. 2014. Biochemical and molecular characterization of potential phosphate-solubilizing bacteria in acid sulfate soils and their beneficial effects on rice growth. PLoS One 9(10): e97241.

Prasad, G., James, E.K., Mathan, N., Reddy, P.M., ReinholdHurek, B. \& Ladha, J.K. 2001. Endophytic colonization of rice by a diazotrophic strain of Serratia marcescens. $J$. Bacteriol. 183: 2634-2645.

Ranneklev, S. \& Baath, E. 2001. Temperature-driven adaptation of the bacterial community in peat measured by using thymidine and leucine incorporation. Appl. Environ. Microbiol. 67: 1116-1122.

Reitz, D. \& Haynes, R. 2003. Effects of irrigation-induced salinity and sodicity on soil microbial activity. Soil Biol. Biochem. 35: 845-854.

Richardson, C.J. \& Marshall, P.E. 1986. Processes controlling movement, storage, and export of phosphorus in a fen peatland. Ecol. Monogr. 56: 279-302.

Rinnan, R., Rousk, J., Yergeau, E., Kowalchuk, G.A. \& Baath, E. 2009. Temperature adaptation of soil bacterial communities along an Antarctic climate gradient: Predicting responses to climate warming. Global Change Biol. 15: 2615-2625.

Rousk, J., Frey, S.D. \& Baath, E. 2012. Temperature adaptation of bacterial communities in experimentally warmed forest soils. Global Change Biol. 18: 3252-3258.

Scheffer, F. \& Schachtschabel, P. 1989. Lehrbuch der Bodenkunde. Enke Verlag, Stuttgart, Germany. p. 491. 
Setia, R., Marschner, P., Baldock, J., Chittleborough, D., Smith, P. \& Smith, J. 2011. Salinity effects on carbon mineralization in soils of varying texture. Soil Biol. Biochem. 43(9): 1908-1916.

Siqueira Neto, M., Scopel, E., Corbeels, M., Nunes Cardoso, A., Douzet, J.M., Feller, C., Piccolo, M.C., Cerri, C.C. \& Bernoux, M. 2010. Soil carbon stocks under no-tillage mulchbased cropping systems in the Brazilian Cerrado: An on-farm synchronic assessment. Soil Tillage Res. 110: 187-195.

Suter, H.C., Pengthamkeerati, P., Walker, C. \& Chen, D. 2011. Influence of temperature and soil type on inhibition of urea hydrolysis by $\mathrm{N}$-(nbutyl) thiophosphoric triamide in wheat and pasture soils in South Eastern Australia. Soil Res. 49: 315-319.

Thangarajan, R., Bolan, N.S., Naidu, R. \& Surapaneni, A. 2015. Effects of temperature and amendments on nitrogen mineralization in selected Australian soils. Environ. Sci. Pollut. Res. Int. 22(12): 8843-8854.

Thompson, L.M. \& Black, C.A. 1947. The effect of temperature on the mineralization of soil organic phosphorus. Soil Sci. Soc. Amer. Proc. 12: 323-326.

Tibbles, B.J. \& Harris, J.M. 1996. Use of radio labelled thymidine and leucine to estimate bacterial production in soils from the continental Antarctica. Appl. Environ. Microbiol. 62: 694-701.

van Gestel, N.C., Dhungana, N., Tissue, D.T. \& Zak, J.C. 2016. Seasonal microbial and nutrient responses during a 5 -year reduction in the daily temperature range of soil in a Chihuahuan Desert ecosystem. Oecologia 180(1): 265-277.

Walkley, A.C. \& Black, T.A. 1935. Estimation of soil organic carbon by chromic acid titration method. Soil Sci. 47: 29-38

Walpola, B. \& Arunakumara, K. 2010. Effect of salt stress on decomposition of organic matter and nitrogen mineralization in animal manure amended soils. J. Agr. Sci. 5: 9-18.

Whalen, J.K., Chang, C. \& Olson, B.M. 2001. Nitrogen and phosphorus mineralization potentials of soils receiving repeated annual cattle manure applications. Biol. Fertil. Soils 34: 334-341.

Xe, R., Tong, C.L., Sun, Z.L., Tang, G.Y., Xiao, H.A. \& Wu, J.S. 2007. Effects of temperature on organic carbon mineralization in paddy soils with different clay content. The Journal of Applied Ecology 18(10): 2245-2250.
Xu, X., Niu, S., Sherry, R.A., Zhou, X., Zhou, J.Y. \& Luo, Y. 2012. Inter annual variability in responses of belowground net primary productivity (NPP) and NPP partitioning to long-term warming and clipping in a tallgrass prairie. Global Change Biol. 18: 1648-1656.

Yuan, B.C., Li, Z.Z., Liu, H., Gao, M. \& Zhang, Y.Y. 2007. Microbial biomass and activity in salt affected soils under arid conditions. Appl. Soil Ecol. 35: 319-328.

Umme Aminun Naher*, Imran Ullah Sarker, Afsana Jahan \& Jatish Chandra Biswas

Soil Science Division

Bangladesh Rice Research Institute

Gazipur-1701

Bangladesh

Md. Maniruzzaman

Irrigation and Water Management Division

Bangladesh Rice Research Institute

Gazipur-1701

Bangladesh

Apurba Kanti Choudhury

On Farm Research Division

Bangladesh Agricultural Research Division

Gazipur-1701

Bangladesh

Navin Kalra

Krishi Gobeshona Foundation

Farmgate, Dhaka-1215

Bangladesh

*Corresponding author; email: naher39@gmail.com

Received: 11 July 2017

Accepted: 5 February 2019 